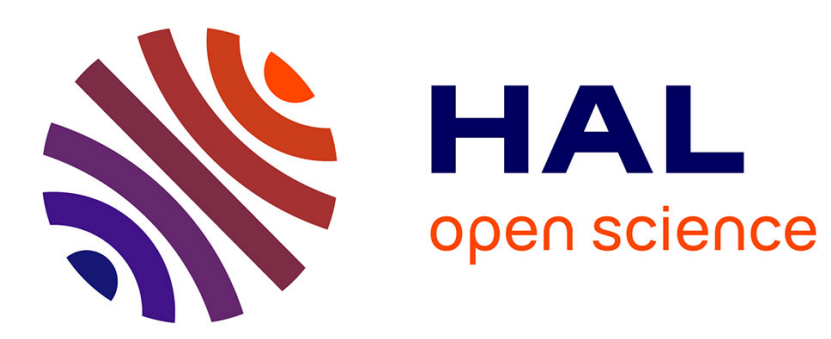

\title{
First green lacewing (Insecta: Neuroptera: Chrysopidae) from the Paleocene Sanshui Basin of Guangdong, South China
}

Diying Huang, Xinneng Lian, Corentin Jouault, Jian Gao, André Nel

\section{To cite this version:}

Diying Huang, Xinneng Lian, Corentin Jouault, Jian Gao, André Nel. First green lacewing (Insecta: Neuroptera: Chrysopidae) from the Paleocene Sanshui Basin of Guangdong, South China. Historical Biology, 2022, 34 (4), pp.704-712. 10.1080/08912963.2021.1943381 . insu-03272764

HAL Id: insu-03272764

https://hal-insu.archives-ouvertes.fr/insu-03272764

Submitted on 28 Jun 2021

HAL is a multi-disciplinary open access archive for the deposit and dissemination of scientific research documents, whether they are published or not. The documents may come from teaching and research institutions in France or abroad, or from public or private research centers.
L'archive ouverte pluridisciplinaire HAL, est destinée au dépôt et à la diffusion de documents scientifiques de niveau recherche, publiés ou non, émanant des établissements d'enseignement et de recherche français ou étrangers, des laboratoires publics ou privés. 


\title{
Historical Biology
}

First green lacewing (Insecta: Neuroptera: Chrysopidae) from the Paleocene Sanshui Basin of Guangdong, South China

Diying Huanga, *, Xinneng Lian ${ }^{\mathrm{a}}$, Corentin Jouault ${ }^{\mathrm{b}, \mathrm{c}}, \mathrm{Jian}_{\mathrm{Gao}}^{\mathrm{a}}$ and André Nel ${ }^{\mathrm{b}, *}$

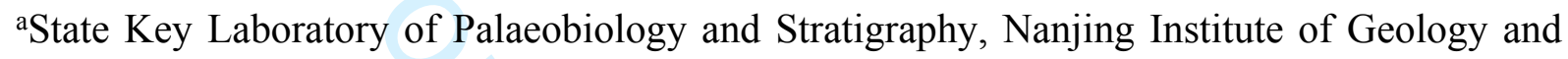
Palaeontology and Center for Excellence in Life and Paleoenvironment, Chinese Academy of Sciences, 39 East Beijing Road, Nanjing 210008, PR China; 'bnstitut de Systématique, Évolution, Biodiversité (ISYEB) Muséum national d'Histoire naturelle, CNRS, Sorbonne Université, EPHE, Université des Antilles, CP50, 57 rue Cuvier 75005 Paris, France; 'Univ. Rennes, CNRS, Géosciences Rennes, UMR 6118, 35000, Rennes, France

*Corresponding authors: dyhuang@nigpas.ac.cn; anel@mnhn.fr

\begin{abstract}
Sinonothochrysa zhangi Huang and Nel gen. et sp. nov., a new genus and species of nothochrysine lacewing, is described and illustrated from the Paleocene Buxin Formation, Sanshui Basina, Foshan City, Guangdong Province, South China. The new taxon is the oldest described representative and first report this subfamily in China. It is also the first formally described fossil insects from the Buxin Formation of the Sanshui Basin.
\end{abstract}

\section{KEYWORDS}

Neuroptera; Nothochrysinae; fossil insects; Buxin Formation; middle Paleocene 


\section{Introduction}

The family Chrysopidae, also called green lacewings due to the color of their extant representatives, is a widespread group of Neuroptera, which has a quite rich fossil record, comprising more than 20 fossil genera and more than 60 fossil species (compared to other Neuroptera as the Myrmeleontidae) (Table. 1; http://fossilworks.org). Their oldest representatives are dated back from the Jurassic of China and Kazakhstan (e.g. Martynov 1927; Panfilov, 1980; Khramov et al. 2015), but their highest species diversity, in the fossil record, is known during the Paleogene. Representatives of the stem-group appear early in the evolutionary history of the family as the subfamily Limaiinae is known since the Jurassic period (Table. 1), suggesting that the family may be older.

Currently, the family is divided in four subfamilies (viz. Apochrysinae + Chrysopinae + Nothochrysinae + Limaiinae), with the Limaiinae is a strictly fossil subfamily. Each subfamilies present huge disparities in their fossil species diversity (Table. 1) since the subfamily Apochrysinae is completely absent from the fossil record while the two other extant subfamilies possess fossil representatives. Interestingly, while the majority of the fossil record of the Limaiinae is Mesozoic, this group survived the Cretaceous-Cenozoic crisis with some Paleocene and the Eocene representatives, viz. three species in the genus Protochrysa Willmann and Brooks, 1991 from the Paleocene-Eocene of Denmark and the Early Eocene of British Columbia (Nel et al. 2005; Makarkin and Archibald 2013). This scenario is very similar to the fate of the Mammalia Multituberculata that were very diverse during the Mesozoic and became extinct during the Paleocene, well after the K-T crisis. The fossil record of the crown group Chrysopidae is currently only represented by Cenozoic Nothochrysinae and Chrysopinae (Table 1). 
The position of the family Chrysopidae is not fully elucidated and alternative hypotheses are proposed depending on the methods or the analyzed data (e.g. Engel et al. 2018; Vasilikopoulos et al. 2020). Winterton et al. (2019) proposed a molecular phylogenetic analysis of the Chrysopidae, dating the separation of their stem group from their putative sister group Myrmeleontoidea from the late Triassic and their crown group from the early Cretaceous. However, it seems that the Chrysopidae would closely related to the clade (Mantispidae + Berothidae) according to recent molecular analyses (Vasilikopoulos et al. 2020: fig. 1) with a divergence estimate to the early Jurassic. However, the calibration used in this most recent work seem to provide questionable age for the group. In fact, Vasilikopoulos et al. (2020) used the chrysopid fossil species Mesypochrysa cf. intermedia to calibrate the crown-group (Chrysopidae + (Mantispidae + Berothidae)) using a soft minimum constrain set to $158.1 \mathrm{Ma}$ (Vasilikopoulos et al., 2020: additional file 1: table S10), which fits with the datation of the Karabastau Formation of Kazakhstan, dated back to the Callovian/Kimmeridgian (Doludenko and Orlovskaya 1976a, Doludenko and Orlovskaya 1976b) or possibly OxfordianKimmeridgian (Doludenko et al. 1990). Recent study on Yanliao Biota late assemblage i.e. Linglongta biota at the Guancaishan locality was considered correlate to Karatau biota of Kazakhstan (Huang 2015, 2016) that yielded some very similar insects such as Cicadomorpha (Fu et al. 2020). An ash layer appeared less one meter up the fossil insect layer at the Guancaishan locality providing a SIMS zircon U-Pb dating as $157.3 \pm 1.5$ Ma that support Karabastau Formation is more likely an Oxfordian-Kimmeridgian age (Huang 2016). However, the Toarcian genus Protoaristenymphes Nel and Henrotay, 1994 is currently placed in the Mesozoic family Mesochrysopidae and the Chrysopoidea (a superfamily that also comprises the Mesozoic Ascalochrysidae), and would be the oldest known representative of this clade (Nel and Henrotay 1994; Yang et al. 2012; Makarkin et al. 2013), supporting a possible older age for the superfamily, more in accordance with Winterton et al. (2019), even if these last 
authors did not used Protoaristenymphes to calibrate theirs datations. Vasilikopoulos et al. (2020) also ignored the Mesochrysopidae and the genus Protoaristenymphes in their list of fossils used as calibration points. We are aware that the choice of fossil taxa in calibrations is difficult and that applying too much constraints on trees may results in dubious results, but, at least the putative oldest records of the concerned clades should be discussed. Therefore, we wonder if the clade or at least the Chrysopidae could be older than previously thought, and suggest that it would be interesting to explore the Neuroptera phylogeny testing different calibrations of the stem- and crown-groups for each family.

Herein we described a new genus and species of Nothochrysinae from the Paleocene, confirming the important diversity of this subfamily at that time.

\section{Geological setting}

The Paleogene deposit of the Sanshui Basin of South Guangdong Province, South China is developed and detailed hereafter (Fig. 1). This strata is divided into the Xinzhuangcun, the Buxin, the Baoyue, and the Huachong formations from bottom to top. Buxin Formation was established at 1964 for a set of lacustrine deposit comprised dark gray oil shale, mud stone, chalky clay, and sand stone. It was firstly considered as an Eocene or Early Oligocene strata. The age of the Buxin Formation was argued by authors based on different biochronometer with various opinions, summarized by Zhang et al. (1993): 1) Early Eocene by ostracodes, conchostracans, gastropods, and fishes; 2) Late Paleocene-Early Eocene by bivalves; 3) EarlyMiddle Eocene by plant fossils and sporo-pollen studies; 4) Middle Eocene by stoneworts. Later, a systematical biostratigraphic study on ostracods suggested that the Xinzhuangcun, Buxin, and Baoyue formations would be assigned to the Paleocene and the Huachong Formation would be assigned to the Early Eocene. Therefore, the above authors indicated that the age of Buxin Formation could be assigned to the Middle Paleocene (Zhang et al. 2008). A recent integrative 
study on China's Paleogene stratigraphy and timescale indicated that the age of Buxin Formation would range from 62.2 Ma to 59.2 Ma, i.e. late Danian to Selandian-Thanetian boundary, mainly based on a paleomagnetism study (Wang et al. 2019). According to this opinion, the age of the present fossil material could be even as old as $62 \mathrm{Ma}$.

Most isotopic dating of volcanic rocks in the Sanshui Basin used K-Ar method (Guangdong Probincial Bureau of Geology and Mineral Resources 1997) could not provide convincing geochronological ages. A Paleocene age of the Buxin Formation was also supported by a geochronological study that indicated that the volcanic eruption started at approximately $60 \mathrm{Ma}$ in the Sanshui Basin. These authors got two set of ages by zircon U-Pb dating as $59.3 \pm 0.2$ Ma and 56.2 \pm 0.3 Ma. The Buxin Formation is subdivided into four members as Honggang Member, Dagang Member, Fenggang Member, and Gaogang Member from bottom to top. The herein described fossil insect was collected from the lower part of the Honggang Formation. The volcanic rocks in the Paleogene of Sanshui Basin initially appeared in the Honggang Member and particularly occurred at the bottom of the Gaogang Member, and then were widely distributed in the lower parts of the Huachong Formation (Zhang et al. 1993). Therefore, the above isotopic age $59.3 \pm 0.2 \mathrm{Ma}$ and $56.2 \pm 0.3 \mathrm{Ma}$ more likely corresponds to the volcanic events of the bottom Gaogang Member of Buxin Formation and the Lower part of the Huachong Formation respectively. This opinion would indicate that the age of the present insect layer is about 61-62 Ma approximately. A correspondence of these two volcanic rock layers with the lower and upper parts of the Buxin Formation cannot be excluded. Then, the age of this fossil insect layer would be 60-59 Ma approximately. To briefly summarize, the age of the lower part of the Buxin Formation that yielded numerous fossil insects would belong to the Middle Paleocene, very close to the famous French volcano-sedimentary maar deposit of Menat in age (60-61 Ma; e.g. Nel and Auvray 2006; Wappler et al. 2009). Nevertheless, both localities with rich fossil entomofaunas need future better accurate isotopic dating. 
The fossil insects from the Sanshui Basin have been found from the Buxin and the Baoyue formations but without a systematically collecting and study. These fossil insects were identified by Qibin Lin (NIGPAS) including Laodiscis melanis, Nisocercopis sp., Platokoleos sp. etc., all taxa that firstly described from the Paleogene of Mengla County, Yunnan Province, Southwestern China (Zhang et al. 1993). The so-called Mengyejing Formation at Shangyong of Mengla County yielded a very rich fossil entomofauna (e.g. Lin 1977; Lin et al. 2010a, b), and its age was also discussed by authors. Analyses of spore-pollen assemblages suggested a Paleogene age for the 'Mengyejing' Formation at Shangyong, but a Late Cretaceous age was not excluded (Nanjing Institute of Geology and Palaeontology et al. 1975). Study of conchostracans suggested an early Eocene age i.e. Ypresian (Chen and Shen 1980; Shen and Chen 1984; Shen et al. 2006). This entomofauna was considered as Eocene (Lin 1977) or Paleocene (Hong 1984) respectively. For the general analysis, the insect-rich layer of the Buxin Formation at the Sanshui Basin and 'Mengyejing' Formation at Shangyong are correlated and both would be Paleocene.

\section{Material and method}

The specimen describe herein derives from the chalky clay of lower part of Honggang Member, Buxin Formation at western of Sanshui District, Foshan City, Guangdong Province, about 40 km west of Guangzhou, the capital of the province (Fig. 1).

The holotype of Sinonothochrysa zhangi Huang and Nel gen. et sp. nov. is an imprint/compression fossil with three-dimensional preservation. It is a nearly complete insect with well-preserved wing venation but the body structures are damaged by crystallization. The specimen was examined and photographed with a LeicaMZ APO and a Canon EOS 5DMark II camera. All images are digitally stacked photomicrographic composites of several individual focal planes, which were obtained using a Zeiss Discovery V20 stereo microscope. The figures 
and drawings were composed with Adobe Illustrator CC2019 and Photoshop CC2019 softwares. The holotype specimen presented herein is housed in NIGPAS, Nanjing Institute of Geology and Palaeontology, Chinese Academy of Science, China under the accession number NIGP175154. Wing venation nomenclature follows Breitkreuz et al. (2017) and in part Brooks and Barnard (1990).

Abbreviations are as follows: A anal vein; bsx basal subcostal crossvein; $\mathrm{C}$ costa; $\mathrm{C} 1$ and $\mathrm{C} 2$ first and second cubital cells; CuA cubitus anterior; $\mathrm{CuP}$ cubitus posterior; dec discal cubital cell; ig inner gradate crossveins; im intramedian cell; MA media anterior; MP media posterior; M1 and M2 first and second median cells; og outer gradate crossveins; Psc Pseudo-cubital vein; Psm pseudo-median vein RA radius anterior; RP radius posterior; ScP subcostal posterior.

Published work and nomenclatural acts are registered in ZooBank urn:lsid:zoobank.org:pub:16ED73C0-9126-4313-837E-D2A76B8738C8.

\section{Systematic palaeontology}

Order Neuroptera Linnaeus, 1758

Family Chrysopidae Schneider, 1851

Subfamily ?Nothochrysinae Navás, 1910

Sinonothochrysa Huang and Nel, gen. nov. urn:1sid:zoobank.org:act:176B7F87-BA8C-4CCF-80A5-2121B79C9FEF

Type species

Sinonothochrysa zhangi n. sp. 


\section{Diagnosis}

Forewing characters. Two series of gradate crossveins; cell im nearly quadrangular and very broad, twice as long as broad, with its anterior side curved; vein Psm with three branches of RP entering it, Psm continued by inner gradates; crossvein $2 \mathrm{~m}$-cu at basal third of cell im; series of cells between Psm and Psc distinctly broader than long; inner gradate series anteriorly curved.

\section{Etymology}

Named after the Latin name 'Sina' for China, and the extant genus name Nothochrysa McLachlan, 1868.

Sinonhothochrysa zhangi Huang and Nel sp. nov.

Figs 2-3

urn:1sid:zoobank.org:act:0238777A-68AE-453D-A83B-2A793B4F06DC

\section{Etymology}

Named after Prof. Xianqiu Zhang, Chinese senior palaeontologist who made a systematically biostratigraphic study of the Sanshui Basin. The specific epithet is to be treated as a noun in the genitive case.

\section{Type material}

Holotype NIGP175154 (crystallized body with complete but superposed right fore- and hind wings and fragments of the left fore- and hind wings).

Type locality

Sanshui District, Foshan City, Guangdong Province, China. 


\section{Stratigraphic occurrence}

Middle Paleocene, Buxin Formation at Western of Sanshui District.

\section{Diagnosis}

As for the genus.

\section{Description}

Body ca. $5.0 \mathrm{~mm}$ long; thorax ca. $1.0 \mathrm{~mm}$ wide.

Forewing (Figs 2-3), $9.0 \mathrm{~mm}$ long, ca. $2.2 \mathrm{~mm}$ wide; apex rounded; costal space poorly preserved, with simple subcostal veinlets relatively widely spaced; ScP very long, with apex not preserved but probably entering margin near wing apex; subcostal space moderately broad; proximal subcostal crossvein (bsx or 1scp-r) present; no other crossvein between ScP and RA detected; tympanum not detectable; RA long, entering margin at wing apex; origin of RP relatively close to wing base, at $3.0 \mathrm{~mm}$ of it; length of RP proximad $1 \mathrm{r}-\mathrm{m} 10$ times as long as 1r-m; RA space (between RA and RP) broad, with 10 crossveins, the most basal one being well distal to $1 \mathrm{r}-\mathrm{m}$; RP weakly zigzagged, with 10 branches, two of them entering Psm; basal crossvein $1 \mathrm{r}-\mathrm{m}$ very short, perpendicular to $\mathrm{M}$, connecting RP with MA; M forked at an open angle opposite origin of RP; intramedian cell very broad, only two times as long as broad, broadly rectangular with anterior side strongly curved; MA not proximally fused with RP1; Psm well-developed, slightly zigzagged and distally prolonged by inner row of gradates; MP distally fused with $\mathrm{CuA}$; Psc with three-four simple branches between it and posterior wing margin; cells between Psm and Psc rather short but very broad; Psc distally prolonged by outer row of gradates; basal crossvein $1 \mathrm{~m}-\mathrm{cu}$ short, apparently located basal to origin of $\mathrm{CuP} ; 2 \mathrm{~m}-$ cu present between MP and $\mathrm{CuA}$ at basal third of cell im; anal and $\mathrm{CuP}$ veins incompletely; 
two complete gradate series of crossveins, outer series not parallel to posterior wing margin; inner series not parallel to outer series; wing membrane apparently hyaline, only darkened in distal part of ScP (pterostigma).

Hind wing (Figs 2-3) ca. $8.8 \mathrm{~mm}$ long, ca. $2.1 \mathrm{~mm}$ wide; apex acute; costal space not preserved; only basal part of ScP visible, subcostal space as broad as that of forewing; proximal subcostal crossvein (bsx or 1scp-r) present; no other crossvein between ScP and RA detected; RA long, entering margin at wing apex; origin of RP relatively close to wing base, at ca. $1.1 \mathrm{~mm}$ of it; length of basal part of RP as long as part fused with MA; RA space (between RA and RP) broad, with 11 crossveins; RP weakly zigzagged, with eigth branches, three of them entering Psm; $M$ forked at an open angle slightly basal to origin of RP; MA distally fused with RP1 and separating again; Psm well-developed, slightly zigzagged and distally prolonged by inner row of gradates; MP distally fused with $\mathrm{CuA}$; Psc with four simple branches between it and posterior wing margin; cells between Psm and Psc large, rather short but very broad; Psc distally prolonged by outer row of gradates; intracubital crossveins $\mathrm{C} 1$ and $\mathrm{C} 2$ and anal veins not preserved except for forked first anal vein; two complete gradate series of crossveins, wing membrane apparently hyaline.

\section{Discussion}

After the key to the extant chrysopid subfamilies of Brooks and Barnard (1990: 132), Sinonothochrysa gen. nov. falls in the Nothochrysinae because of the character 'forewing Psm continuous with inner row of gradates'. Tauber (2014) proposed a list of putative apomorphies of the Nothochrysinae and two groups of genera, but none of these are preserved in our specimen. Makarkin and Archibald (2013) considered the character 'Psm not extending to the outer row of gradates' as possibly characteristic of the Nothochrysinae. They also have the 
crossvein $2 \mathrm{~m}$-cu located in the proximal half of im. This character is also present in some Chrysopinae, but not in the Cretaceous-Paleogene Limaiinae.

Garzón-Orduña et al. (2019) listed nine extant genera in the Nothochrysinae, viz. Nothochrysa McLachlan, 1868, Pimachrysa Adams, 1957, and Hypochrysa Hagen, 1866, Asthenochrysa Adams and Penny, 1992, Leptochrysa Adams and Penny, 1992, Pamochrysa Tjeder, 1966, Kimochrysa Tjeder, 1966 (considered as a subjective synonym of Hypochrysa by Tauber, 2014), Triplochrysa Kimmins, and Dictyochrysa Esben-Petersen (Tjeder 1966; Adams 1967; Adams and Penny 1992). Several fossil genera are currently put in this subfamily (Table 1), viz. Adamsochrysa Makarkin and Archibald, 2013 (Eocene), Archaeochrysa Adams, 1967 (Eocene to Oligocene), Asiachrysa Makarkin, 2014 (Eocene), Dyspetochrysa Adams, 1967 (Oligocene), Lithochrysa Carpenter, 1935 (Oligocene), Okanaganochrysa Makarkin and Archibald, 2013 (Eocene), Palaeochrysa Scudder, 1890 (Oligocene), Pronothochrysa Peñalver et al., 1995 (Miocene), Pseudochrysopa Makarkin and Archibald, 2013 (Eocene), and Tribochrysa Scudder, 1890 (Oligocene). As Winterton et al. (2019) found the Nothochrysinae as paraphyletic in their phylogenetic analysis, the exact positions of all these fossils remain questionable.

Dictyochrysa and Triplochrysa are excluded from consideration because the gradate crossveins in Sinonothochrysa gen. nov. are arranged in two series only (vs. more than two in these genera, see respectively Brooks and Barnard 1990: fig. 527; New 1980: fig. 13). Pamochrysa has the forewing cell im rhomboidal, while it is nearly quadrangular in Sinonothochrysa gen. nov. (Brooks and Barnard 1990: fig. 554).

Sinonothochrysa gen. nov. shares with Kimochrysa a forewing cell im ca. twice as long as broad, unlike the genus Nothochrysa in which im is much narrower (Adams 1967: fig. 3; Kovanci and Canbulat 2007; Tauber 2019). But the forewing cells im of the Kimochrysa spp. are triangular or pentagonal (Tjeder 1966; Adams 1978; Brooks and Barnard 1990: fig. 539). 
Hypochrysa elegans (Burmeister, 1839) and Asthenochrysa (type species A. viridula (Adams, 1978)) have also a triangular cell im (Adams 1967: fig. 5, 1978: fig. 1; Brooks and Barnard 1990: fig. 533). In Sinonothochrysa gen. nov., the anterior side of the cell im is curved, while in Kimochrysa impar Tjeder, 1966, it is slightly angular, rendering im pentagonal (Tjeder 1966: fig. 785), the difference being rather weak. Nevertheless, the vein 'distal part of MA - Psm' is much shorter in K. impar and K. africana (Kimmins, 1937) than in Sinonhothochrysa gen. nov., with only two short cells above it basal to the first i.g. vein instead of three large ones.

While Pimachrysa grata Adams, 1957, P. fusca Adams, 1967 and P. intermedia Adams, 1967 have rather narrow cells im, $P$. nigra Adams, 1967 has one nearly ca. twice as long as broad as in Sinonothochrysa gen. nov. (Adams 1957: fig. 1, 1967: figs 1-2, 4). They all differ from Sinonothochrysa gen. nov. in the crossvein $2 \mathrm{~m}$-cu basal or very close to basal angle of cell im and the series of cells between Psm and Psc nearly as long as broad.

Leptochrysa has a very particular cell im, quadrangular but with the cell below it strongly reduced (Adams and Penny 1992: fig. 10; Tauber 2019), strongly differing from the configuration of im in Sinonothochrysa gen. nov. (pentagonal without reduction of the cell below it).

Okanaganochrysa has two series of cells between Psm and Psc (Makarkin and Archibald 2013: fig. 4). The Adamsochrysa spp. have a hexagonal cell im, but broadly similar to that of Sinonothochrysa gen. nov. (Makarkin and Archibald 2013: fig. 6), but they also have four rows of gradate crossveins. The Archaeochrysa spp. have a quadrangular cell im, but much narrower than in Sinonothochrysa gen. nov. (Adams 1967; Makarkin and Archibald 2013). Makarkin and Archibald (2013) provisionally put Pseudochrysopa in the Nothochrysinae because of the two following characters: 'Psm does not extend to the outer gradate series'; and ' $2 \mathrm{~m}$-cu is located in the proximal half of im'. The exact position of this genus needs to be re- 
evaluated. Nevertheless, it strongly differs from Sinonothochrysa gen. nov. in the narrower cell im and vein Psm not continued by the inner gradates.

Dyspetochrysa vetuscula (Scudder, 1890), Tribochrysa inaequalis Scudder, 1885, Tribochrysa firmata Scudder, 1890, Lithochrysa wickhami (Cockerell, 1914), Palaeochrysa stricta Scudder, 1890 and P. creedei Carpenter, 1935 differ from Sinonothochrysa gen. nov. in the elongate cell im, a course of the inner gradates parallel to posterior wing margin, instead of being anteriorly curved (Carpenter 1935: figs 1, 3-4, 6-7). Palaeochrysa fracta Cockerell, 1914 has also a narrow cell im and an irregular series of inner gradates (maybe an aberrant feature) (Carpenter 1935: fig. 2).

Pronothochrysa vivesi Peñalver et al., 1995 has also a narrow cell im, plus a much longer vein 'distal part of MA - Psm' than in Sinonothochrysa gen. nov. with six cells between it and RP instead of three (Peñalver et al. 1995: fig. 4).

Asiachrysa tadushiella Makarkin, 2014 has a cell im similar to that of Sinonothochrysa gen. nov., although slightly narrower. Nevertheless, its cells between Psm and Psc are longer and narrower than in Sinonothochrysa gen. nov. and overall, the crossvein $2 \mathrm{~m}$-cu is situated below mid part of cell im instead of being in the basal third of this cell (Makarkin 2014: fig. 3).

\section{Conclusion}

Except for a Miocene genus, the fossil record of the subfamily Nothochrysinae is restricted to the Eocene - Oligocene, with an impressive diversity during the Eocene to the earliest Oligocene with ten described extinct genera contra only one (Nothochrysa) during the Middle - Late Oligocene, confirmed by the newly described genus. Possibly this subfamily collapsed during the Oligocene in relation to the general cooling and/or bat diversification, as already suggested by Archibald et al. (2014) and Ngô-Muller et al. (2019). The Paleocene 
Sinonothochrysa zhangi Huang and Nel gen. nov. et sp. nov. is the oldest record of the Nothochrysinae.

\section{Acknowledgements}

We thank two anonymous reviewers for their constructive comments. Financial support was provided by the Strategic Priority Research Program of the Chinese Academy of Sciences (XDB18000000 and XDB26000000), and the National Natural Science Foundation of China (41925008 and 41688103).

\section{References}

Adams PhA. 1957. A new genus and new species of Chrysopidae from the Western United States, with remarks on the wing venation of the family (Neuroptera). Psyche 63:67-74. doi.org/10.1155/1956/47287

Adams PhA. 1967. A review of the Mesochrysinae and Nothochrysinae (Neuroptera: Chrysopidae). Bulletin of the Museum of Comparative Zoology 135:215-238. creativecommons.org/licenses/by-nc-sa/3.0/

Adams PhA. 1978. New species of Hypochrysa and a new subgenus and species of Mallada (Neuroptera, Chrysopidae). Pan-Pacific Entomologist 54:292-296.

Adams PhA, Penny ND. 1992. New genera of Nothochysinae from South America. Pan-Pacific Entomologist 68:216-221.

Ansorge J, Schlüter T. 1990. The earliest chrysopid: Liassochrysa stigmatica n. g., n. sp. from the Lower Jurassic of Dobbertin, Germany. Neuroptera International 6:87-93.

Archibald SB, Makarkin VN. 2015. A new species of Archaeochrysa Adams (Neuroptera: Chrysopidae) from the early Eocene of Driftwood Canyon, British Columbia, Canada. The Canadian Entomologist 147:359-369. doi.org/10.4039/tce.2014.53 
Archibald SB, Makarkin VN. 2017. A new fossil green lacewing (Neuroptera: Chrysopidae) from the early Eocene Driftwood Canyon, Canada. Zootaxa 4324:397-400. doi.org/10.11646/zootaxa.4324.2.13

Archibald SB, Makarkin VN, Greenwood DR, Gunnell GF. 2014. The Red Queen and court jester in green lacewing evolution: bat predation and global climate change. Palaios 29:185191. doi.org/10.2110/palo.2013.089

Breitkreuz LCV, Winterton SL, Engel MS. 2017. Wing tracheation in Chrysopidae and other Neuropterida (Insecta): a resolution of the confusion about vein fusion. American Museum Novitates 3890:1-44. doi.org/10.1206/3890.1

Brooks SJ, Barnard PC. 1990. The green lacewings of the World: a generic review (Neuroptera: Chrysopidae). Bulletin of the British Museum, (Natural History), Entomology 59:117-286. creativecommons.org/licenses/by-nc-sa/4.0/

Burmeister H. 1839. Handbuch der Entomologie, Reimer (publ.), Berlin, 1:1-400.

Carpenter FM. 1935. Tertiary insects of the family Chrysopidae. Journal of Paleontology 9:259-271. jstor.org/stable/1298167

Chen P-J, Shen Y-B. 1980. On the Paraleptestheria menglaensis fauna with reference to the age of the Lofochai Group. Acta Palaeontologica Sinica 19:182-189 (In Chinese with English Summary).

Cockerell TDA. 1909. Two fossil Chrysopidae. The Canadian Entomologist 41:218-219. doi.org/10.4039/Ent41218-7

Cockerell TDA. 1914. New and little-known insects from the Miocene of Florissant, Colorado. Journal of Geology 22:714-724. https://doi.org/10.1086/622186

Doludenko, MP, Orlovskaya, E.R. 1976a. Jurassic floras of the Karatau Range, southern Kazakhstan. Palaeontology 19:627-640. go.palass.org/3zu

Doludenko MP, Orlovskaya ER. 1976b. Jurassic flora of Karatau. Nauka, Moscow (In Russian). 
Doludenko MP, Sakulina GV, Ponomarenko AG. 1990. The geology and Late Jurassic fauna and flora of a unique locality Aulie (Karatau Mountains, Southern Kazakhstan) Geologicheskii Institut AN SSSR, Moscow (In Russian)

Engel MS, Grimaldi DA. (2007. The neuropterid fauna of Dominican and Mexican amber (Neuropterida: Megaloptera, Neuroptera). American Museum Novitates 3587:1-58. doi.org/10.1206/3587.1

Fu Y-z, Cai C-y, Huang D-y. 2019. A new palaeontinid (Insecta, Hemiptera, Cicadomorpha) from the Upper Jurassic Tiaojishan Formation of northeastern China and its biogeographic significance. Journal of Paleontology 94:513-520. doi: 10.1017/jpa.2019.95.

Garzón-Orduña IJ, Winterton SL, Jiang Y-1, Breitkreuz LCV, Duelli P, Engel MS, Penny ND, Tauber CA, Mochizuki A, Liu X-y. 2019. Evolution of green lacewings (Neuroptera: Chrysopidae): a molecular supermatrix approach. Systematic Entomology 44:499-513. doi.org/10.1111/syen.12339

Guangdong Probincial Bureau of Geology and Mineral Resources. 1997 Lithologic Stratigraphy of Guangdong Province. Wuhan: China University of Geosciences Press:264 pp.

Handschin E. 1937. Fossile Insekten aus Siebenbürgen. Mitteilungen der Schweizerischen Entomologischen Gesellschaft 17:25-29.

Hong Y-c. 1984. Tertiary insects of China. In: Li Y-t. (Ed.), The Tertiary System of China. Beijing: Geological Publishing House:308-309.

Huang D-y. 2015. Yanliao biota and Yanshan movement. Acta Palaeontologica Sinica 54:501546 [In Chinese].

Huang D-y. 2016. The Daohugou Biota. Shanghai Scientific and Technical Publishers, Shanghai:332 pp. [In Chinese]. 
Jepson JE, Makarkin VN, Coram RA. 2012. Lacewings (Insecta: Neuroptera) from the Lower Cretaceous Purbeck Limestone Group of southern England. Cretaceous Research 34:31-47. doi.org/10.1016/j.cretres.2011.10.001

Khramov AV, Liu Q, Zhang H-C, Jarzembowski EA. 2015. Early green lacewings (Insecta: Neuroptera: Chrysopidae) from the Jurassic of China and Kazakhstan. Papers in Palaeontology 2:25-39. doi.org/10.1002/spp2.1024

Kimmins DE. 1937. A new African Hypochrysa (Neuroptera). Annals and Magazine of Natural History (10) 19:307-308. doi.org/10.1080/00222933708655265

Khramov AV. 2018. A new assemblage of Early Cretaceous green lacewings (Chrysopidae: Neuroptera) from Transbaikalia. Earth and Environmental Science Transactions of the Royal Society of Edinburgh 107:195-202. doi.org/10.1017/S1755691017000342

Kovanci B, Canbulat S. 2007. A new species of the genus Nothochrysa McLachlan 1868 from northwestern Turkey (Neuroptera: Chrysopidae) with a key to western Palaearctic species. Annales de la Société Entomologique de France (N.S.) 43:165-168. doi.org/10.1080/00379271.2007.10697507

Lin Q-b. 1977. Fossil insects of Yunnan. In: Nanjing Institute of Geology and Palaeoentomology (Ed.), Mesozoic fossils of Yunnan. Science Press, Beijing: 373-384.

Lin Q-b, Petrulevičius JF, Huang D-y, Nel A, Engel MS. 2010a. First fossil Calopterygoidea from Southeastern Asia (Odonata: Zygoptera): a new genus and species from the Paleogene of China. Geobios 43:349-353. doi.org/10.1016/j.geobios.2009.11.005

Lin Q-b, Szwedo J, Huang D-y, Stroiński A. 2010b. Weiwoboidae fam. nov. of 'higher' Fulgoroidae (Hemiptera: Fulgoromorpha) from the Eocene deposits of Yunnan, China. Acata Geologica Sinica (English Edition) 84:751-755. doi.org/10.1111/j.17556724.2010.00263.x 
Lu X-m, Wang B, Ohl M, Liu X-y. 2018. The first green lacewing (Insecta: Neuroptera: Chrysopidae) from the mid-Cretaceous amber of Myanmar. Zootaxa 4399:563-570. doi.org/10.11646/zootaxa.4399.4.6

Makarkin VN. 1991. Miocene insects (Neuroptera) from the northern Caucasus and SikhoteAlin. Paleontological Journal 25:55-65.

Makarkin VN. 1994. Upper Cretaceous Neuroptera from Russia and Kazakhstan. Annales de la Société Entomologique de France (N.S.) 30:283-292.

Makarkin VN. 1997. Fossil Neuroptera of the Lower Cretaceous of Baisa, east Siberia. Part 3. Chrysopidae (Insecta). Spixiana 20:107-118.

Makarkin VN. 2014. A new fossil green lacewing (Neuroptera: Chrysopidae) from the Eocene Tadushi Formation, eastern Sikhote-Alin. Far Eastern Entomologist 272:1-7.

Makarkin VN, Archibald SB. 2013. A diverse new assemblage of green lacewings (Insecta, Neuroptera, Chrysopidae) from the Early Eocene Okanagan Highlands, Western North America. Journal of Paleontology 87:123-146. doi.org/10.1666/12-052R.1

Makarkin VN, Yang Q, Shi C-f, Ren D. 2013. The presence of the recurrent veinlet in the Middle Jurassic Nymphidae (Neuroptera): a unique character condition in Myrmeleontoidea. ZooKeys 325:1-20. doi.org/10.3897/zookeys.325.5453

Makarkin VN, Wedmann S, Weiterschan T. 2018. The first green lacewings from the late Eocene Baltic amber. Acta Palaeontologica Polonica 63:527-537. doi.org/10.4202/app.00504.2018

Martins-Neto RG. 1997. Neurópteros (Insecta, Planipennia) da Formação Santana (Cretáceo Inferior), Bacia do Araripe, Nordeste do Brasil. X - descrição de novos táxons (Chrysopidae, Babinskaiidae, Myrmeleontidae, Ascalaphidae e Psychopsidae). Revista da Universidade de Guarulhos, Ciências Exatas e Tecnológicas 2:68-83. 
Martins-Neto RG, Vulcano MA. 1988. Neurópteros (Insecta, Planipennia) da Formação Santana (Cretáceo Inferior), Bacia do Araripe, nordeste do Brasil. I - Família Chrysopidae. Anais da Academia Brasileira de Ciências 60:189-201.

Martynov AV. 1927. Jurassic fossil Insects from Turkestan. 7. Some Odonata, Neuroptera, Thysanoptera. Izvestiya Akademii Nauk SSSR 21:757-768.

Nanjing Institute of Geology and Palaeontology, Bureau of Geology and Mineral Resources of Yunnan Province and Bureau of Metallurgy of Yunnan Province Geological Company. 1975. Mesozoic Red Beds of Yunnan. Science Press, Beijing:1-201 (In Chinese).

Nanjing Institute of Geology and Palaeontology, Bureau of Geology and Mineral Resources of Yunnan Province and Bureau of Metallurgy of Yunnan Province Geological Company. 1975. Mesozoic Red Beds of Yunnan. Science Press, Beijing: 1-201 (In Chinese).

Nel A, Delclòs X, Hutin A. 2005. Mesozoic chrysopid-like Planipennia: a phylogenetic approach (Insecta: Neuroptera). Annales de la Société Entomologique de France (N.S.) 41:29-69. doi.org/10.1080/00379271.2005.10697440

Nel. A, Auvray F. 2006. The oldest Vespinae from the Paleocene of Menat (France) (Hymenoptera: Vespidae). Zootaxa 1344:59-62. doi.org/10.11646/zootaxa.1344.1.5

Nel A, Séméria Y. 1986. Une nouvelle espèce de chrysopide fossile du Stampien supérieur (Oligocène) d'Aix-en-Provence Notochrysa stampieni sp. nov. (Neuroptera, Chrysopidae, Notochrysinae). Neuroptera International 4:23-30.

New TR. 1980 A revision of the Australian Chrysopidae (Insecta: Neuroptera) Australian Journal of Zoology, Supplementary Series 77:1-143. https://doi.org/10.1071/AJZS077

Ngô-Muller V, Blot K, Nel A. 2019. A new species of Nothochrysa from the latest Oligocene of France (Insecta: Neuroptera: Chrysopidae). Palaeoentomology 2:111-114. doi.org/10.11646/palaeoentomology.2.2.2 
Panfilov DV. 1980. Novye predstaviteli setcharokrylykh (Neuroptera) iz yury Karatau [New representative of Neuroptera from the Jurassic in the Karatau region.] pp. 82-111. In: Dolin VG, Panfilov DV, Ponomarenko AG, Pritykina LN. (eds). Iskopajemye nasekomyje mezozoja. [Fossil insects of the Mesozoic.] Akademiya nauk Ukrainskoj SSR, Institut Zoologii, Naukova Dumka, Kiev, 135 pp. [in Russian.]

Peñalver E, Nel A, Martínez-Delclòs X. 1995. New Nothochrysinae from the Spanish Miocene (Neuroptera: Chrysopidae). Bulletin de la Société Entomologique de France 100:481-487. www.persee.fr/doc/bsef_0037-928x_1995_num_100_5_17194

Ponomarenko AG. 1992. Novye setchatokrylye (Insecta: Neuroptera) iz mezozoya Mongolii. Novye Taksony Iskopaemykh Bespozvonochnykh Mongolii. Sovmestnaya RossiiskoMongol'skaya Paleontologicheskaya Ekspeditsiya 41:101-111.

Ren D, Guo Z-G. 1996 On the new fossil genera and species of Neuroptera (Insecta) from the Late Jurassic of northeast China. Acta Zootaxonomica Sinica 21:461-479.

Schlüter T. 1982. Cimbrochrysa moleriensis n. g. sp. nov. und Hypochrysa hercyniensis sp. nov., zwei fossile Chrysopidae-Arten (Insecta: Planipennia) aus dem europäischen Tertiär. Neues Jahrbuch für Geologie und Paläontologie, Monatshefte 1982:257-264.

Scudder SH. 1885. 4. Classe Insecta. Insecten. Handbuch der Palaeontologie, I Abtheilung. Palaeozoologie 2:747-831.

Scudder SH. 1890. The Tertiary insects of North America. Report of the United States Geological Survey of the Territories 13:1-734.

Séméria Y, Nel A 1990. Paleochrysopa monteilsensis gen. et sp. nov., a new fossil of Chrysopidae from the Upper Eocene Formation of Monteils (France), with a review of known chrysopid fossils (Insecta: Neuroptera). Advances in Neuropterology. Proceedings of the Third International Symposium on Neuropterology: 27-32. 
Shen Y-b, Chen P-j. 1984. Tertiary conchostracans of China. In: Li Y-t. (ed.), The Tertiary System of China. Beijing: Geological Publishing House: 306-308.

Shen Y-b., Gallego OF, Buchheim HP, Biaggi RE. 2006. Eocene conchostracans from the Laney Member of the Green River Formation, Wyoming, USA. Journal of Paleontology 80:447-454. doi.org/10.1666/0022-3360(2006)80[447:ECFTLM]2.0.CO;2

Statz S. 1936. Über neue Funde von Neuropteren, Panorpaten und Trichopteren aus dem Tertiaren schiesfern von Rott am Siebengebirge. Decheniana 93:208-255.

Tauber CA. 2014. Nothochrysinae (Neuroptera: Chrysopidae): new larval description and generic synonymy, with a consideration of generic relationships. Psyche 2014 (ID 839261):1-10. doi.org/10.1155/2014/839261

Tauber CA. 2019. South American Nothochrysinae (Neuroptera, Chrysopidae): I. Description of Nothochrysa ehrenbergi sp. nov. ZooKeys 86:1-18. doi.org/10.3897/zookeys.866.35394

Tauber CA. 2019. South American Nothochrysinae (Neuroptera, Chrysopidae): II. Redescription of Leptochrysa prisca Adams \& Penny. ZooKeys 866:19-38. doi.org/10.3897/zookeys.866.35396

Tjeder B. 1966. Neuroptera-Planipennia. The lace-wings of Southern Africa. 5. Family Chrysopidae. pp. 228-534. In: Hanström B, Brinck P, Rudebec G. (eds.). South African Animal Life, Swedish Natural Science Research Council, Stockholm, 12.

Vasilikopoulos, A., Misof, B., Meusemann, K., Lieberz, D., Flouri, T., Beutel, R.G., Niehuis, O., Wappler, T., Rust, J., Peters, R.S., Donath, A., Podsiadlowski, L., Mayer, C., Bartel, D., Böhm A, Liu, S-1, Kapli P, Greve C, Jepson JE, Liu X-y, Zhou, X, Aspöck H, Aspöck U. 2020. An integrative phylogenomic approach to elucidate the evolutionary history and divergence times of Neuropterida (Insecta: Holometabola). BMC Evolutionary Biology 20:1-24. doi.org/10.1186/s12862-020-01631-6 
Wang Y-q, Li Q, Bai B, Jin X, Mao F-y, Meng J. 2019. Paleogene integrative stratigraphy and timescale of China. Science China Earth Science 62:287-309.

Wappler T, Currano ED, Wilf P, Rust J, Labandeira CC. 2009. No post-Cretaceous ecosystem depression in European forests? Rich insect-feeding damage on diverse middle Palaeocene plants, Menat, France. Proceedings of Royal Society of London B 276:4271-4277. doi.org/10.1098/rspb.2009.1255

Willmann R. 1993. Insekten aus der Fur-Formation von Dänemark (Moler, ob. Paleozän/unt. Eozän? 8. Zwei neue Vertreter der Chrysopidae (Neuroptera). Neues Jahrbuch für Geologie und Paläontologie, Monatshefte 1993:239-245.

Willmann R, Brooks SJ. 1991. Insekten aus der Fur-Formation von Dänemark (Moler, ob. Paleozän/unt. Eozän ?). 6. Chrysopidae (Neuroptera). Meyniana 43:125-135.

Winterton SL, Gillung JP, Garzón-Orduña IJ, Badano D, Breitkreuz LCV, Duelli P, Engel MS, Liu X-g, Machado RJP, Mansell M, Mochizuki A, Penny ND, Tauber CA, Oswald JD. 2019. Evolution of green lacewings (Neuroptera: Chrysopidae): an anchored phylogenomics approach. Systematic Entomology 44:514-526. https://doi.org/10.1111/syen.12347

Yang J-K, Hong Y-c. 1990. Drakochrysa, an Early Cretaceous new genus of Chrysopidae (Insecta: Neuroptera) from Laiyang basin, Shandong Province. Geoscience - Journal of Graduate School, China University of Geosciences 4:15-26.

Yang Q, Makarkin VN, Ren D 2012. New fossil Mesochrysopidae (Neuroptera) from the Mesozoic of China. Zootaxa 3597:1-14. doi.org/10.11646/zootaxa.3597.1.1

Zhang X-q, Li G, Yang R-1, Li H-m. 2008. Palaeogene ostracods from the Sanshui Basin of Guangdong. Acta Micropalaeontologica Sinica 25:235-265.

Zhang X-q, Zhou X-p, Chen X-y. 1993. Atlas of Cretaceous to Tertiary strata classification and correlation in the Sanshui Basin of South China. Marine Press, Beijing: 183 pp. 
Zhou H-m, Xiao L, Dong Y-x, Wang C-z, Wang F-z, Ni P-z. 2009. Geochemical and geochronological study of the Sanshui basin bimodal volcanic rock suite, China: Implications for basin dynamics in southeastern China. Journal of Asian Earth Sciences 34:178-189. doi.org/10.1016/j.jseaes.2008.05.001

Table 1. Fossil record of the family Chrysopidae

Figure 1. Fossil locality map.

Figure 2. Sinonhothochrysa zhangi Huang and Nel gen. et sp. nov., holotype NIGP175154. (A) photograph of habitus; (B) forewing reconstruction; arrows: course of forewing $\mathrm{CuP} ;(\mathbf{C})$ hind wing reconstruction. Scale bars $=1 \mathrm{~mm}$.

Figure 3. Sinonhothochrysa zhangi Huang and Nel gen. et sp. nov., holotype NIGP175154. Photographs. (A) thorax with bases of wings; (B) detail of bases of wings. Scale bars $=1 \mathrm{~mm}$ (A), $0.5 \mathrm{~mm}(\mathrm{~B})$ 


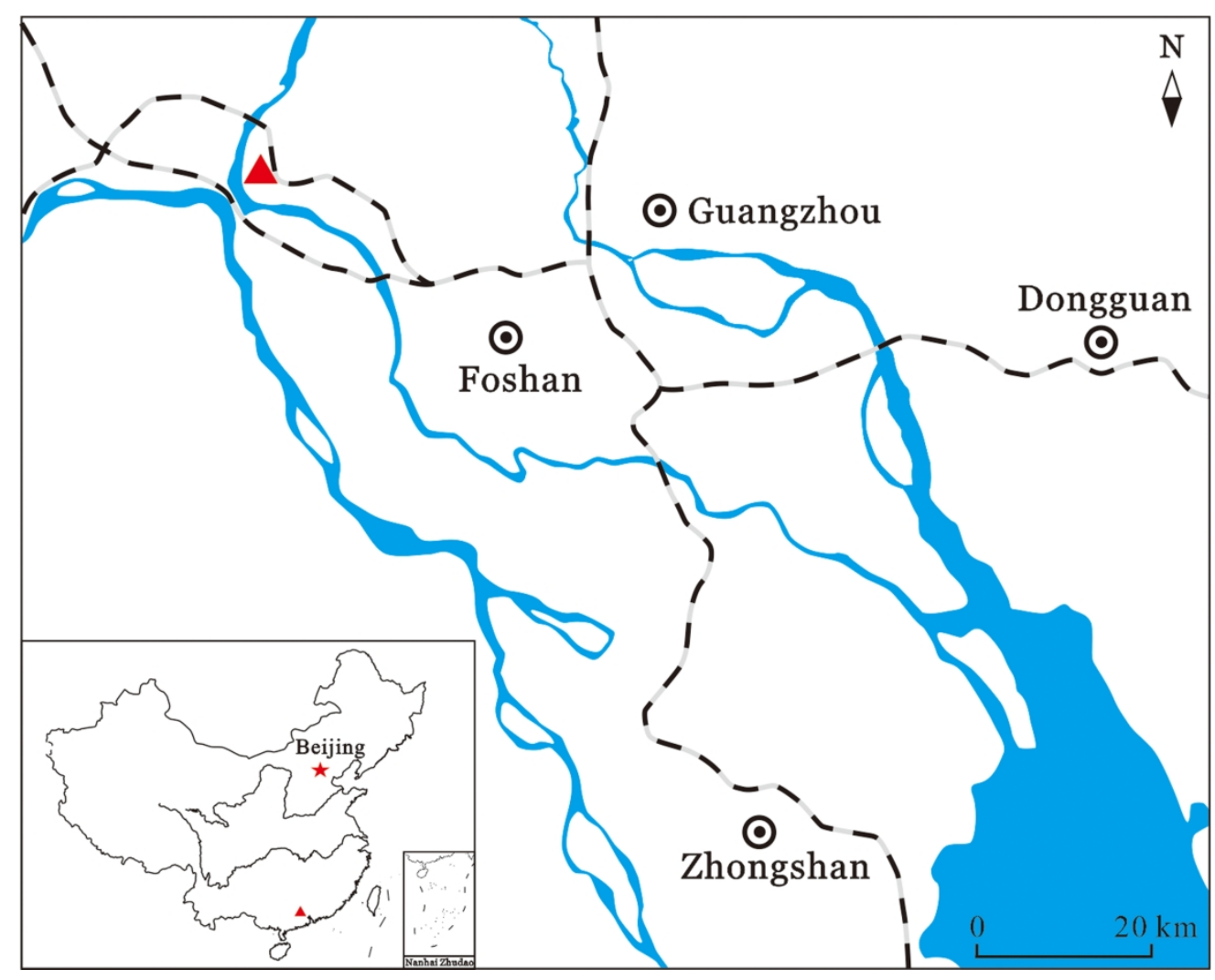

figure 1 

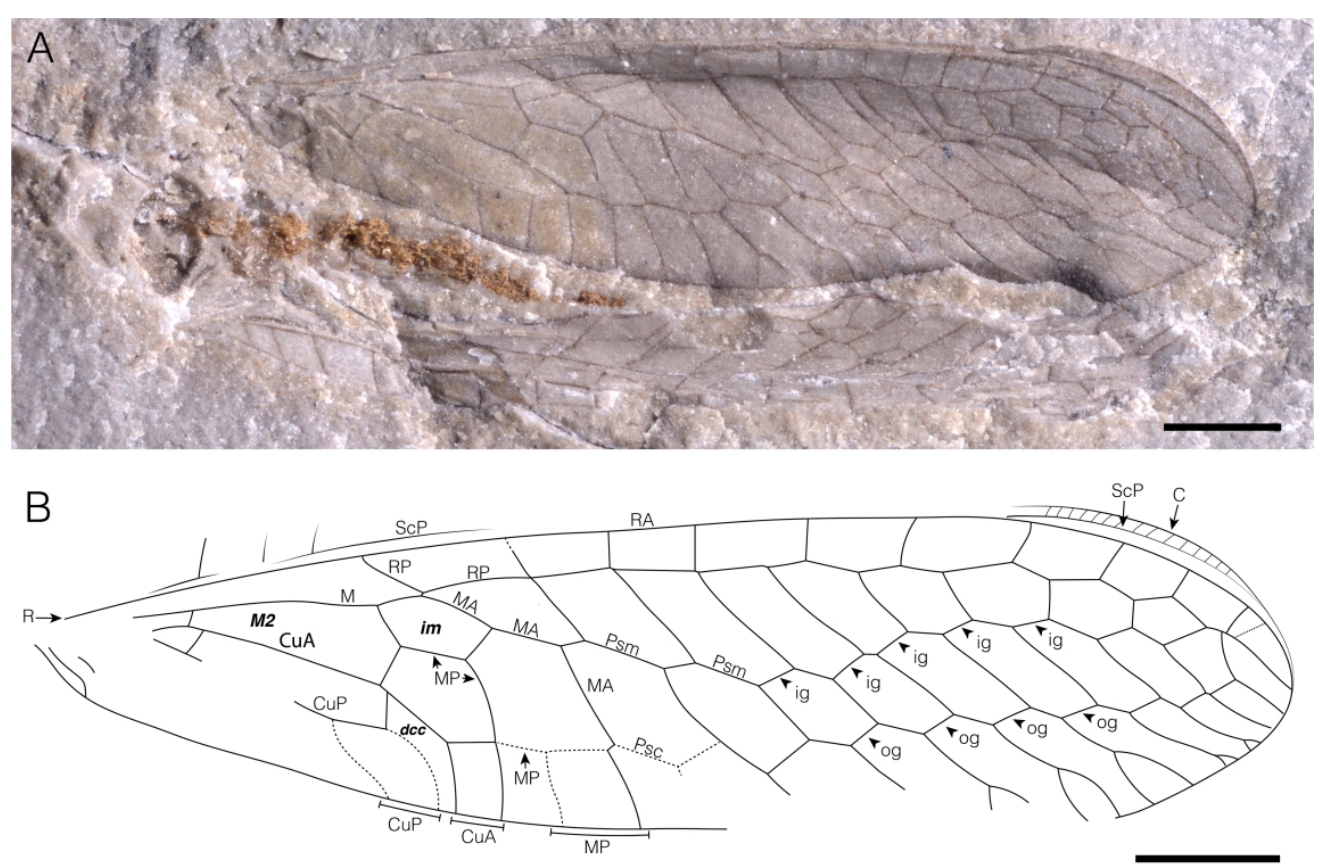

C

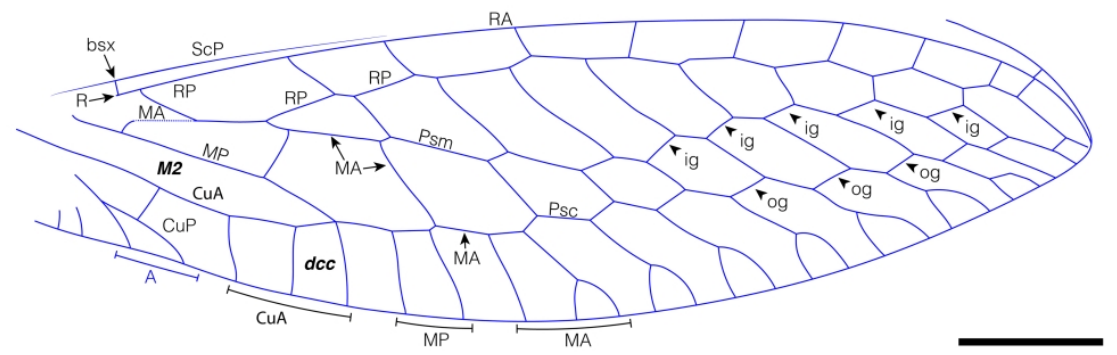

figure 2 


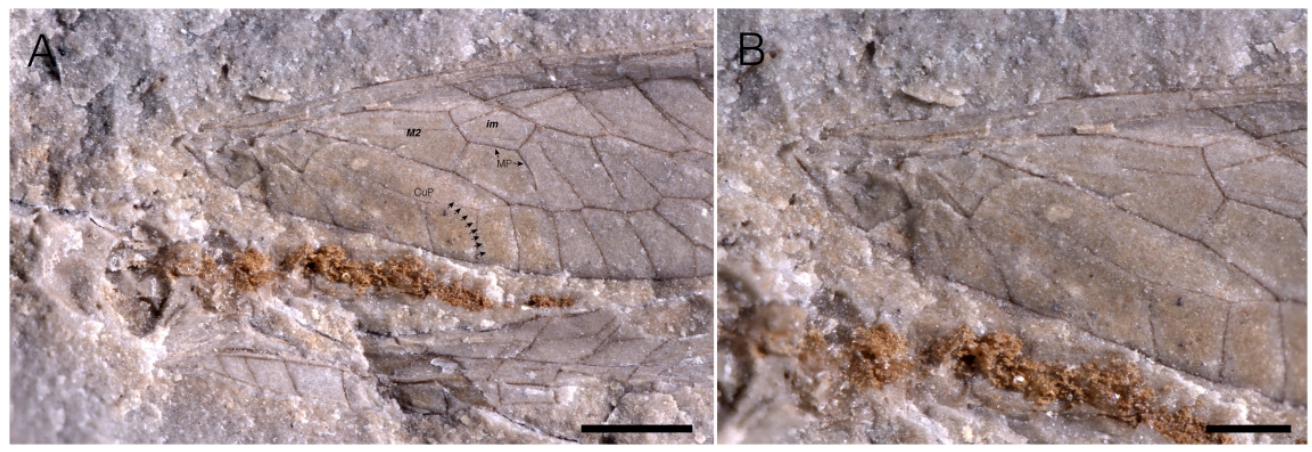

figure 3 


\begin{tabular}{|c|c|c|c|}
\hline Subfamily / Tribe / Genus & Species & Distribution & Age \\
\hline \multicolumn{4}{|l|}{ Subfamily uncertain } \\
\hline \multicolumn{4}{|l|}{ Cimbrochrysa Schlüter, 1982} \\
\hline & C. moleriensis Schlüter, 1982 & Denmark & Ypresian \\
\hline \multicolumn{4}{|l|}{ Cretachrysa Makarkin, 1994} \\
\hline & C. martynovi Makarkin, 1994 & Russian Federation & Campanian \\
\hline \multicolumn{4}{|l|}{ Danochrysa Willmann, 1993} \\
\hline & D. madseni Willmann, 1993 & Denmark & Ypresian \\
\hline \multicolumn{4}{|l|}{ Paralembochrysa Nel et al., 2005} \\
\hline & P. splendida Nel et al., 2005 & China & Aptian \\
\hline \multicolumn{4}{|l|}{ Stephenbrooksia Willmann, 1993} \\
\hline & S. multifurcata Willmann, 1993 & Denmark & Ypresian \\
\hline \multicolumn{4}{|l|}{ Chrysopinae Schneider, 1851} \\
\hline \multirow[t]{2}{*}{ Paleochrysopa Séméria \& Nel, 1990} & 28 & & \\
\hline & P. monteilsensis Séméria \& Nel, 1990 & France & Priabonian \\
\hline \multicolumn{4}{|l|}{ Pseudosencera Makarkin et al., 2018} \\
\hline & P. baltica Makarkin et al., 2018 & Russian Federation & Priabonian \\
\hline & 28 & & \\
\hline \multicolumn{4}{|l|}{ Chrysopini Schneider 1851} \\
\hline \multirow[t]{7}{*}{ Chrysopa Leach, 1815} & $8+3$ & & \\
\hline & C. glaesaria Engel \& Grimaldi, 2007 & Dominican Republic & Burdigalian/Langhian \\
\hline & C. martynovae Makarkin, 1991 & Russian Federation & Miocene \\
\hline & C. miocenea Makarkin, 1991 & Russian Federation & Miocene \\
\hline & C. sarmatica Handschin, 1937 & Romania & middle Serravallian \\
\hline & C. stavropolitana Makarkin, 1991 & Russian Federation & Miocene \\
\hline & C. vetula Engel \& Grimaldi 2007 & Dominican Republic & Burdigalian/Langhian \\
\hline & & $P$ & \\
\hline \multicolumn{4}{|l|}{ Leucochrysini Adams 1978} \\
\hline \multicolumn{4}{|l|}{ Leucochrysa McLachlan, 1868} \\
\hline & L. (Nodita) prisca Engel \& Grimaldi, 2007 & Dominican Republic & Burdigalian/Langhian \\
\hline \multicolumn{4}{|c|}{ Limaiinae Martins-Neto and Vulcano, 1988} \\
\hline \multicolumn{4}{|l|}{ Aberrantochrysa Khramov, 2018} \\
\hline & A. buryatica Khramov, 2018 & Russian Federation & Aptian \\
\hline & A. pulchella Khramov, 2018 & Russian Federation & Aptian \\
\hline \multicolumn{4}{|c|}{ Araripechrysa Martins-Neto \& Vulcano, 1988} \\
\hline & $\begin{array}{l}\text { A. magnifica Martins-Neto \& Vulcano, } \\
\text { 1 noo }\end{array}$ & Brazil & Aptian \\
\hline \multicolumn{4}{|l|}{ Baisochrysa Makarkin, 1997} \\
\hline & B. multinervis Makarkin, 1997 & Russian Federation & Aptian \\
\hline & B. pumila Khramov et al., 2015 & Kazakhstan & Callovian/Oxfordian \\
\hline \multicolumn{4}{|l|}{ Drakochrysa Yang \& Hong, 1990} \\
\hline & D. sinica Yang \& Hong, 1990 & China & Aptian \\
\hline \multicolumn{4}{|l|}{ Limaia Martins-Neto \& Vulcano, 1988} \\
\hline & L. adicotomica Martins-Neto, 1997 & Brazil & Aptian \\
\hline
\end{tabular}


1

3

\begin{tabular}{|c|c|c|c|}
\hline & $\begin{array}{l}\text { L. conspicua Martins-Neto \& Vulcano, } \\
\text { tnon }\end{array}$ & Brazil & Aptian \\
\hline \multicolumn{4}{|l|}{ Mesypochrysa Martynov, 1927} \\
\hline & M. angustialata Makarkin, 1997 & Russian Federation & Aptian \\
\hline & M. cannabina Khramov, 2018 & Russian Federation & Aptian \\
\hline & M. chrysopa Makarkin, 1997 & Russian Federation & Aptian \\
\hline & M. chrysopoides Ponomarenko, 1992 & Mongolia & Aptian \\
\hline & M. curvimedia Makarkin, 1997 & Russian Federation & Aptian \\
\hline & M. falcata Makarkin, 1997 & Russian Federation & Aptian \\
\hline & M. intermedia Panfilov, 1980 & Kazakhstan & Callovian/Oxfordian \\
\hline & M. latipennis Martynov, 1927 & Kazakhstan & Callovian/Oxfordian \\
\hline & M. magna Makarkin, 1997 & Russian Federation & Aptian \\
\hline & M. minima Makarkin, 1997 & Russian Federation & Aptian \\
\hline & M. miniscula Ren \& Guo, 1996 & China & Aptian \\
\hline & M. minuta Jepson et al., 2012 & United Kingdom & Berriasian \\
\hline 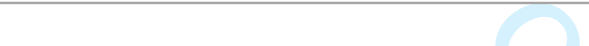 & M. naranica Khramov, 2018 & Russian Federation & Aptian \\
\hline 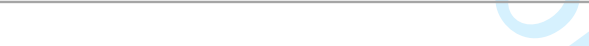 & M. polyclada Panfilov, 1980 & Kazakhstan & Callovian/Oxfordian \\
\hline$P$ & M. polyneura Ren \& Guo, 1996 & China & Aptian \\
\hline & M. reducta Panfilov, 1980 & Kazakhstan & Callovian/Oxfordian \\
\hline & M. sinica Khramov et al., 2015 & China & Callovian/Oxfordian \\
\hline \multicolumn{4}{|l|}{ Parabaisochrysa Lu et al., 2018} \\
\hline & P. xingkei $\mathrm{Lu}$ et al., 2018 & Myanmar & Cenomanian \\
\hline & $P r$ & & \\
\hline \multicolumn{4}{|l|}{ Protochrysa Willmann \& Brooks, 1991} \\
\hline & P. aphrodite Willmann \& Brooks, 1991 & Denmark & Ypresian \\
\hline & P. fuscobasalis Makarkin \& Archibald, & Canada & Ypresian \\
\hline \multicolumn{4}{|l|}{ Nothochrysinae Navas 1910} \\
\hline \multicolumn{4}{|l|}{ Adamsochrysa Makarkin \& Archibald, 2013} \\
\hline & A. aspera Makarkin \& Archibald, 2013 & Canada & Ypresian \\
\hline & A. wilsoni Makarkin \& Archibald, 2013 & Canada & Ypresian \\
\hline & & $\infty$ & \\
\hline \multicolumn{4}{|l|}{ Archaeochrysa Adams, 1967} \\
\hline & A. creedei Carpenter, 1935 & USA & Oligocene \\
\hline & A. fracta Cockerell, 1914 & USA & earliest Oligocene \\
\hline & A. paranervis Adams, 1967 & USA & earliest Oligocene \\
\hline & A. profracta Makarkin \& Archibald, 2013 & 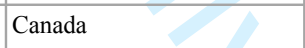 & Ypresian \\
\hline & A. sanikwa Archibald \& Makarkin, 2015 & Canada & Ypresian \\
\hline \multicolumn{4}{|l|}{ Asiachrysa Makarkin, 2014} \\
\hline & A. tadushiella Makarkin, 2014 & Russian Federation & Ypresian \\
\hline \multicolumn{4}{|l|}{ Dyspetochrysa Adams, 1967} \\
\hline & D. vetuscula Scudder, 1890 & USA & earliest Oligocene \\
\hline \multicolumn{4}{|l|}{ Hypochrysa Gould, 1861} \\
\hline & H. hercyniensis Schlüter, 1982 & Germany & Pliocene \\
\hline \multicolumn{4}{|l|}{ Lithochrysa Carpenter, 1935} \\
\hline & L. borealis Archibald \& Makarkin, 2017 & Canada & Ypresian \\
\hline & L. wickhami Cockerell, 1914 & USA & earliest Oligocene \\
\hline Nothochrysa MacLachlan, 1868 & & & \\
\hline
\end{tabular}




\begin{tabular}{|c|c|c|c|}
\hline & N. praeclara Statz, 1936 & Germany & Chattian \\
\hline & N. stampieni Nel \& Séméria, 1986 & France & Chattian \\
\hline & N. praeclara Statz, 1936 & Germany & Chattian \\
\hline \multicolumn{4}{|c|}{ Okanaganochrysa Makarkin \& Archibald, 2013} \\
\hline & O. coltsunae Makarkin \& Archibald, 2013 & Canada & Ypresian \\
\hline \multicolumn{4}{|l|}{ Palaeochrysa Scudder, 1890} \\
\hline & P. concinnula Cockerell, 1909 & USA & Chadronian \\
\hline & P. stricta Scudder, 1890 & USA & Chadronian \\
\hline \multicolumn{4}{|c|}{ Pronothochrysa Peñalver et al., 1995} \\
\hline & P. vivesi Peñalver et al., 1995 & Spain & Miocene \\
\hline \multicolumn{4}{|c|}{ Pseudochrysopa Makarkin \& Archibald, 2013} \\
\hline & P. harveyi Makarkin \& Archibald, 2013 & Canada & Ypresian \\
\hline \multicolumn{4}{|l|}{ Sinonothochrysa gen. nov. } \\
\hline & Sinonothochrysa eocenica sp. nov. & China & middle Paleocene \\
\hline & 10 & & \\
\hline \multicolumn{4}{|l|}{ Tribochrysa Scudder, 1885} \\
\hline & T. firmata Scudder, 1890 & USA & Chadronian \\
\hline & T. inequalis Scudder, 1885 & USA & Chadronian \\
\hline
\end{tabular}


1

2

3

4

5

6

7

8

9

10

11

12

13

14

15

16

17

18

19

20

21

22

23

24

25

26

27

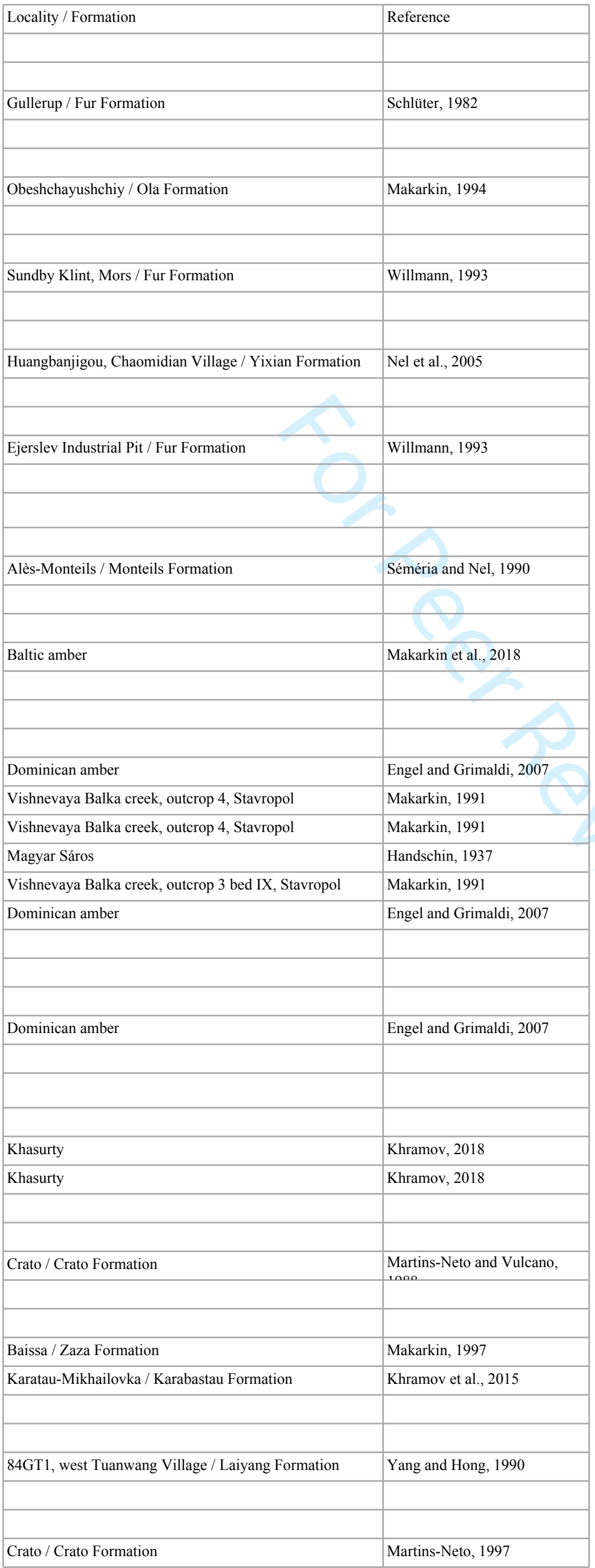


1

2

3

4

5

6

7

8

9

10

11

12

13

14

15

16

17

18

19

20

21

22

23

24

25

26

27

28

29

30

31

32

33

34

35

36

37

38

39

40

41

42

43

44

45

46

47

\begin{tabular}{|c|c|}
\hline Crato / Crato Formation & Martins-Neto, 1988 \\
\hline Baissa / Zaza Formation & Makarkin, 1997 \\
\hline Khasurty & Khramov, 2018 \\
\hline Baissa / Zaza Formation & Makarkin, 1997 \\
\hline Bon Tsagaan / Dzun-Bain Formation & Ponomarenko, 1992 \\
\hline Baissa / Zaza Formation & Makarkin, 1997 \\
\hline Baissa / Zaza Formation & Makarkin, 1997 \\
\hline Karatau-Mikhailovka / Karabastau Formation & Panfilov, 1980 \\
\hline Galkino / Karabastau Formation & Martynov, 1927 \\
\hline Baissa / Zaza Formation & Makarkin, 1997 \\
\hline Baissa / Zaza Formation & Makarkin, 1997 \\
\hline Near Chaomidian Village / Yixian Formation & Ren and Guo, 1996 \\
\hline $\begin{array}{l}\text { Durlston Bay, Bed DB175, Swanage (Manchester Mus) / } \\
\text { Durlston Formation }\end{array}$ & Jepson et al., 2012 \\
\hline Khasurty & Khramov, 2018 \\
\hline Karatau-Mikhailovka / Karabastau Formation & Panfilov, 1980 \\
\hline Near Chaomidian Village / Yixian Formation & Ren and Guo, 1996 \\
\hline Karatau-Mikhailovka / Karabastau Formation & Panfilov, 1980 \\
\hline Daohugou / Daohugou Formation & Khramov et al., 2015 \\
\hline Burmese amber & Lu et al., 2018 \\
\hline Fur Formation & Willmann and Brooks, 1991 \\
\hline McAbee & Makarkin and Archibald, 2013 \\
\hline McAbee & Makarkin and Archibald, 2013 \\
\hline McAbee & Makarkin and Archibald, 2013 \\
\hline Creede / Creede Formation & Carpenter, 1935 \\
\hline Wilson Ranch, Florissant & Cockerell, 1914 \\
\hline Florissant, Station 14 / Florissant Formation & Adams, 1967 \\
\hline McAbee & Makarkin and Archibald, 2013 \\
\hline Driftwood Canyon & Archibald and Makarkin, 2015 \\
\hline Tadushi locality / Tadushi Formation & Makarkin, 2014 \\
\hline Florissant / Florissant Formation & Scudder, 1890 \\
\hline Willershausen clay pit & Schlüter, 1982 \\
\hline Driftwood Canyon & Archibald and Makarkin, 2017 \\
\hline Florissant / Florissant Formation & Cockerell, 1914 \\
\hline
\end{tabular}




\begin{tabular}{|l|l|}
\hline Rott / Rott Formation & Statz, 1936 \\
\hline Plâtrières, Aix-en-Provence & Nel and Séméria, 1986 \\
\hline Rott / Rott Formation & Statz, 1936 \\
\hline & \\
\hline McAbee & \\
\hline & Makarkin and Archibald, 2013 \\
\hline & \\
\hline Florissant / Florissant Formation & \\
\hline Florissant / Florissant Formation & Cockerell, 1909 \\
\hline & Scudder, 1890 \\
\hline & \\
\hline La Rinconada, Ribesalbes & \\
\hline & Peñalver et al., 1995 \\
\hline & \\
\hline Driftwood Canyon & \\
\hline & Makarkin and Archibald, 2013 \\
\hline & \\
\hline Sanshui District / Buxin Formation & \\
\hline & This paper \\
\hline & \\
\hline Florissant / Florissant Formation & \\
\hline
\end{tabular}

